\title{
Development of Specific Nano-Antibody for Application in Selective and Rapid Environmental Diagnoses of
}

\section{Salmonella arizonae}

\author{
Basem S. Ahmed 1, Amr Ahmed Mostafa 1, Osama M. Darwesh 2, *iD, Emam A. Abdel-Rahim ${ }^{1}$ \\ 1 Biochemistry Department, Faculty of Agriculture, Cairo University, Egypt \\ 2 Agricultural Microbiology Dept., National Research Centre, Dokki, Cairo, Egypt \\ * Correspondence: darweshosama@yahoo.com;
}

Scopus Author ID 56128096000

Received: 8.05.2020; Revised: 2.06.2020; Accepted: 3.06.2020; Published: 7.06.2020

\begin{abstract}
Treatment of human and animals for protection from pathogens infection has significant economic value, especially with the harmful Salmonella arizonae. Beneficial cameloid heavy-chain antibodies as single-domain antigen-binding fragments known as VHHs or nano-bodies may be the acceptable option for producing the treatment and/or diagnostic agents. In the current study, we developed a sandwich ELISA based nano-body towards S. arizonae as the first report for the treatment of $S$. arizonae. using the cDNA synthesized from immunized camels RNA to isolate 700 bp DNA fragment, which contains all $\mathrm{VH}$ domains of $\mathrm{IgG} 2$ and $\mathrm{IgG} 3$ isotypes followed by the second amplification VHH PCR with amplified fragments at $450 \mathrm{bp}$. The final PCR products were cloned into the phagemid vector pMECS then via phage display technique. Nano-antibodies protein was purified and separated under non-denaturing conditions by SDS-PAGE. The reactivity of each VHH of the selected clones was analyzed by Western blot assay. The isolated nano-antibodies showed binding not only to $S$. arizonae, but also to other bacterial strains, indicating that these nano-antibodies can be used in treatment but cannot use in diagnostic.
\end{abstract}

Keywords: S. arizonae; nano-antibodies; cameloid VHH; environmental treatment.

(C) 2020 by the authors. This article is an open-access article distributed under the terms and conditions of the Creative Commons Attribution (CC BY) license (https://creativecommons.org/licenses/by/4.0/).

\section{Introduction}

Microbial group of Salmonellae is a Gram-negative, facultative, non-spore-forming, bacilli bacteria belonging to Enterobacteriaceae family. It usually causes food-borne diseases. Also, it is a part of bacterial flora found in humans and animals, though the occurrence regularity is variable, reflecting the general level of Salmonella in water, food, and environment [1]. They are widely distributed into environments that have disturbed by human activities. Salmonella arizonae is considered one of the less common Salmonellae members [2]. It was reported firstly by Caldwell and Ryerson in 1939 and named Salmonella dar-es-salaam [3]. Subsequently, it also named S. arizonae, Arizona hinshawii, S. cholerasuis subsp. arizonae and finally re-classified as S. enterica subsp. arizonae in 1983 [4]. S. arizonae was reported to cause the human disease spectrum, including bacteremia, gastroenteritis, vascular infection, joint, and bone infection [5, 6-8]. Cold-blooded animals are the typical $S$. arizonae habitats and other animals like poultry, dogs, and rats $[9,10]$, as well as it has been involved in human infection. Around 20 pediatric patients below 18 years old sorrow from $S$. arizonae infection have been noted in the papers $[11,12]$. 
Hamers-Casterman and his colleagues in 1993 established the antibodies' existence devoid of light chains that are selected as heavy-chain antibodies [13]. The binding sites of antigen include amino acids from only a single variable domain of heavy-chain antibodies (VHHs) [14]. The encoding VHH of DNA ( 400 bp) can be manipulated for cloning, expression, and mutation. For building the phage display library, the VHH coding sequence was bonded with the minor capsid protein $\mathrm{p} 3$ of non-lytic filamentous phage. The nano-body would show on the filamentous phage tip after liberation by the helper phage that provides replication factors for the modified display phage [15]. Compared with conservative monoclonal and polyclonal antibodies, the generation of phage display antibody fragments is cost-effective and time-saving. It is possible to design or modify the DNA sequence of coding the phage-displayed antibody fragments. The recombinant antibodies could be easily expressed in various protein expression hosts. Newly, nano-bodies, which specifically bind to the LM invasion, were isolated by the selection of the non-immunized or immunized VHH library [16].

To find treatment technology for S. arizonae infection, our aim in this study was to develop specific nano-bodies for $S$. arizonae with lower cost and higher stability compared with traditional antibodies. The immune library of phage-displayed nano-body was constructed after immunization of $S$. arizonae camel. S. arizonae-specific VHH antibodies were achieved after biopanning. Furthermore, we have demonstrated the construction of a nanobody-based sandwich ELISA which could be applied in environmental sample analysis.

\section{Materials and Methods}

\subsection{Preparation of Salmonella arizonae vaccine.}

Salmonella arizonae, as pathogenic bacterium used in this study to produce the nanobody for the camel immunization, was kindly obtained from the Egyptian Microbial Culture Collections Network (EMCCN) at National Research Centre (NRC), Cairo, Egypt.

Firstly, the formalin killed vaccine was prepared from activated bacterium culture. A single colony from freshly streaked Salmonella arizonae on nutrient agar plates was inoculated into one flask contained $20 \mathrm{ml}$ tryptic soy broth for immunization at an early stage. The inoculated flask was incubated at $37^{\circ} \mathrm{C}$ overnight at shaking conditions. After incubation, the broth culture was centrifuged at $6000 \mathrm{xg}$ at $4{ }^{\circ} \mathrm{C}$ for $15 \mathrm{~min}$ [17]. The supernatant was decanted, and the precipitated cells were washed twice with acetone followed by twice diethyl ether. The washed cell pellet was re-suspended into $1 \%$ formalin saline, and Tween 80 was added to the suspension with the final concentration of 3-4\%. The suspension was washed three times with Phosphate buffer saline (PBS)/Tween and centrifuged at $6000 \mathrm{xg}$ at $4{ }^{\circ} \mathrm{C}$ for $15 \mathrm{~min}$, and the pellet was dissolved in $500 \mu \mathrm{l}$ PBS as an inactivated bacterial cells for injection into camel [18].

\subsection{Camel Immunization.}

One camel was immunized by intramuscular injection with 6 doses from the prepared Salmonella arizonae vaccine. At zero time, the camel was given the first dose of vaccines emulsified into complete adjuvant (1:1 vaccine to adjuvant). In the other five doses, the vaccines were formulated in incomplete adjuvant (1:1 vaccine to adjuvant) and injected into the camel. The injection was done every week. At the end of immunization, the blood sample was collected in a sterile blood collection tube contained $200 \mu \mathrm{l}$ of $1 \mathrm{M}$ EDTA and then centrifuged at $4500 \mathrm{xg}$ for $10 \mathrm{~min}$ at $4^{\circ} \mathrm{C}$. Plasma was transferred to new $1.5 \mathrm{ml}$ tubes and 
diluted by PBS to $10^{-2}, 10^{-3}$ and $10^{-4}$ to check the immune-response against $S$. arizonae by ELISA technique [19] with few modifications using ELISA reader (BIO TEK ELX800) at 450 $\mathrm{nm}$. The control was used, PBS as a sample against $S$. arizonae coated well.

\subsection{Bactrian camel immunization and nano-body library construction.}

The VHH libraries were constructed as previously presented [20]. Principally, mRNA was isolated from $100 \mathrm{ml}$ blood of vaccinated camel using E.Z.N.A. ${ }^{\circledR}$ Blood RNA Maxi Kit (OMEGA Bio-TEK, USA). All materials were treated by RNase Away (RNase Away, MOLECULAR BIO PRODUCTS, USA). Consequently, the first-strand cDNA was synthesized using SuperScript kit (INVITROGEN, GERMANY) with oligo-dT primers. All VH domains, including the VHH domains from Heavy-chain antibody IgG2 and IgG3 isotypes, were amplified with the primer CALL001 (5' GTCCTGGCTCTCTTCTACAAG 3') and CALL002 (5' GGTACGTGCTGTTGAACTGTT 3') primer [18] in VERITY 96 well, AB, Singapore thermocycler using Fast Start DNA Taq Polymerase (ROCHE, USA). The reaction was performed as follows, a $2 \mu \mathrm{l}$ of cDNA were mixed with $5 \mu \mathrm{l}$ of $10 \mathrm{x}$ Fast Start DNA Taq Polymerase buffer with $\mathrm{MgCl}_{2}, 1 \mu \mathrm{l}$ dNTP's, 10 pmol of each primer (Call 001 and Call 002), and adjusted to a final volume of $50 \mu \mathrm{l}$ by nuclease-free water. PCR amplification was accomplished by denaturation at $94^{\circ} \mathrm{C}$ for $5 \mathrm{~min}$ followed by $35 \mathrm{Cycles}$ of $94^{\circ} \mathrm{C}$ for $30 \mathrm{~s}, 55^{\circ} \mathrm{C}$ for $1 \mathrm{~min}, 72{ }^{\circ} \mathrm{C}$ for $1 \mathrm{~min}$ and terminated with a final extension at $72{ }^{\circ} \mathrm{C}$ for $7 \mathrm{~min}$. The VHH gene fragments (coding for the $\mathrm{Nbs}$ ) were purified from agarose gel and re-amplified using nested primers containing the restriction sites for PstI and NotI restriction VHH (5, GATGTGCAGCTGCAGGAGTCTGGRGG 3') and pMECS (5' CTAGTGCGGCCGCTGAGGAGACGGTG 3') primers using Fast Start DNA Taq polymerase (Roche, USA). $8 \mu$ of purified PCR were mixed with $5 \mu l$ of $10 \times$ Fast Start DNA Taq polymerase buffer with $\mathrm{MgCl}_{2}, 1 \mu \mathrm{dNTP}$ 's, $1 \mu \mathrm{l}$ of $\mathrm{VHH}$ primer, $1 \mu \mathrm{l}$ of pMECS primer and adjusted to final volume of $50 \mu \mathrm{l}$ by nuclease-free water. The cycling conditions were $94^{\circ} \mathrm{C}$ for $5 \mathrm{~min}$ followed by 20 Cycles of $94^{\circ} \mathrm{C}$ for $30 \mathrm{~s}, 55^{\circ} \mathrm{C}$ for $1 \mathrm{~min}, 72^{\circ} \mathrm{C}$ for $1 \mathrm{~min}$, with a final extension at $72^{\circ} \mathrm{C}$ for $7 \mathrm{~min}$ [21]. The final PCR products were cloned into the phagemid vector pMECS. Ligated material was transformed into Escherichia coli TG1 cells by electroporation (BIO-RAD). Colonies were harvested by scraping in the culture medium, washed, and the VHH library stored at $-80^{\circ} \mathrm{C}$ in $\mathrm{LB}$ medium supplemented with glycerol $(30 \%$ final concentration). The transformation of VHH/pMECS into TG1 competent cells was checked through colony PCR for 20 random colonies by using G III (5' CCACAGACAGCCCTCATAG) and MP57 (5' TTATGCTTCCGGCTCGTATG) primers using the following cycling parameters: denaturation at $94^{\circ} \mathrm{C}$ for 5 min and 35 cycles of $94^{\circ} \mathrm{C}$ for $30 \mathrm{~s}, 55^{\circ} \mathrm{C}$ for $30 \mathrm{~s}, 72^{\circ} \mathrm{C}$ for $1 \mathrm{~min}$ with a final extension at $72^{\circ} \mathrm{C}$ for $10 \mathrm{~min}$.

\subsection{Phage Display Enrichment for Specific Binders.}

Production of rescue phage of VHH library (Pan 0) was prepared according to Xue et al. [22] with some modifications. In brief, $2 \mathrm{ml}$ of the library representing cells was diluted in $212 x t y$ media with ampicillin (Amp) at an optical density (OD600) 0.143 and incubated at $37^{\circ} \mathrm{C}$ with shaking until the OD reached to 0.576, then $2 \mathrm{ml}$ of KM13 (M13KO7) helper phage at a concentration of $2 \times 10^{12}$ was added and incubated for $2 \mathrm{~h}$ at $37^{\circ} \mathrm{C}$ without shacking. Finally, 2 $\mathrm{ml}$ of kanamycin (Kan) $\left(200 \mathrm{mg}\right.$ ) was added and incubated at $37^{\circ} \mathrm{C}$ overnight with shaking. The overnight culture was centrifuged at $6000 \mathrm{rpm}$ for $6 \mathrm{~min}$, and the supernatant was mixed 
with $20 \%$ PEG6000/ $2.5 \mathrm{M} \mathrm{NaCl}$ at dilution 4:1, followed by incubation on ice and centrifuged at $3200 \mathrm{xg}$ for $30 \mathrm{~min}$ at $4{ }^{\circ} \mathrm{C}$. The pellet was dried and re-suspended in $12 \mathrm{ml}$ of PBS and centrifuged at $8500 \mathrm{xg}$ for $2 \mathrm{~min}$. The supernatant was mixed with PEG/ $\mathrm{NaCl}$ with a dilution factor of $6: 1$ and centrifuged at $3200 \mathrm{xg}$ for $30 \mathrm{~min}$ at $4^{\circ} \mathrm{C}$. The pallet was re-suspend in $1 \mathrm{ml}$ of PBS and stored at $4^{\circ} \mathrm{C}$.

\subsection{Panning against $S$. arizonae.}

Construction of Pan1 for $S$. arizonae strain was prepared in two wells of ELISA plate (Maxisorb 96-well microtiter plate, NUNC) that was coated by S. arizonae cells and blocked by skimmed milk. A $100 \mu \mathrm{l}$ of Pan0 rescue phage was added to the coated wells and incubated for at least $1 \mathrm{~h}$ at room temperature. The phage solution was removed and discarded in bleaching water. The wells were rinsed 10x with PBS/Tween. To elute bound phages, $100 \mu 1$ of freshly prepared $100 \mathrm{mM}$ triethylamine $(\mathrm{pH} \sim 11.5)$ was added and incubated for $10 \mathrm{~min}$ at room temperature. The eluted phages were transferred to a fresh tube containing an equal volume $(100 \mu \mathrm{l})$ of $1 \mathrm{M}$ Tris $\mathrm{HCl}, \mathrm{pH} 7.4$ to neutralize the solution. After that, $190 \mu \mathrm{l}$ from each tube contains neutralized solution of phage particles was mixed with $2 \mathrm{ml}$ of TG1 cells with $\mathrm{OD}_{600} 0.6$ at $37^{\circ} \mathrm{C}$ for $1 \mathrm{~h}$ without shacking, and then $8 \mathrm{ml}$ of $2 x t y-A m p$ were added and incubated at $37^{\circ} \mathrm{C}$ for $1 \mathrm{~h}$ with shacking, $100 \mu \mathrm{M} 13 \mathrm{k} 07$ helper phage as superinfection were incubated at $37^{\circ} \mathrm{C}$ for $1 \mathrm{~h}$ and diluted in $250 \mathrm{ml} 2 x$ ty-Amp $(100 \mathrm{mg} / \mathrm{ml})-\mathrm{Kan}(100 \mathrm{mg} / \mathrm{ml})$ and incubated at $37^{\circ} \mathrm{C}$ overnight with shacking. One well was coated with $S$. arizonae cells, and the other was coated with PBS as control. A second panning round of enrichment for phages with antigen-specific nano-bodies was started at the next day, where the overnight culture was used instead of the VHH original library as described in Pan1 and the PBS as a control sample. After serial dilutions, the remaining $190 \mu \mathrm{l}$ of phages was discarded in bleaching water, the colony quant in LB agar media with Amp and glucose. Rescue phage was titrated by taking $10 \mu \mathrm{l}$ of the neutralized solution of phage particles and prepared 8-fold serial dilutions of eluted phage followed by mixing $10 \mu \mathrm{l}$ from each dilution with $90 \mu \mathrm{l}$ of Tg1 cells with OD600 0.6 and incubated at $37^{\circ} \mathrm{C}$ for $1 \mathrm{~h}$ then $10 \mu \mathrm{l}$ from each dilution was plated onto the $2 x$ ty-Amp-glucoseagar medium. These steps were repeated from Pan1 to Pan4.

\subsection{Testing of rescue phage against S. arizonae by phage ELISA.}

Rescue phage of $S$. arizonae was screened by coating 4 wells of ELISA plate with 100 $\mu \mathrm{l}$ of $S$. arizonae, then blocked using skimmed milk. The OD of each rescue phage was measured at $260 \mathrm{~nm}$ then diluted to lowest OD value, and $2 \mu 1$ from each dilution was re-diluted to $200 \mu \mathrm{l}$, and $100 \mu \mathrm{l}$ from this solution was added to the coated and control wells and incubated at RT for $1 \mathrm{~h}$. The phage solution was removed and discarded in bleaching water. The wells were rinsed $3 \times$ with PBS/Tween using an antibody (anti M13, 1:1000) followed by TMB, the ELISA plate was read on ELISA reader at $450 \mathrm{~nm}$.

\subsection{Screening for S. arizonae specific nano-antibody by ELISA.}

One ELISA plate was coated by $S$. arizonae cells or carbonate buffer as the control, and all wells were blocked by skimmed milk. 48 colons contain VHH fragment against $S$. arizonae from each were selected, inoculated on $1000 \mu \mathrm{TB}$ medium, and incubated for $5 \mathrm{~h}$ at $37^{\circ} \mathrm{C}$. After the incubation period, $10 \mu \mathrm{l}$ of IPTG was added for each culture and incubated at $37^{\circ} \mathrm{C}$ overnight. The incubated culture was centrifuged at $2054 \mathrm{xg}$ for $15 \mathrm{~min}$, and the pellet was re- 
suspended in $200 \mu \mathrm{l}$ TES buffer and incubated on ice for $45 \mathrm{~min}$ with shaking. And then, 300 $\mu 1$ 1:4 TES buffer was added to the suspension and incubated for $1 \mathrm{~h}$ on ice with shaking. The suspension was centrifuged at $2054 \mathrm{xg}$ for $15 \mathrm{~min}$, and $200 \mu \mathrm{l}$ from each sample was added to the ELISA plate and incubated at room temperature for $1 \mathrm{~h}$. First antibody (anti HA 1:2000), a second antibody (Goat anti-Mouse HRP 1:2000), and the substrate (TMB) were used, ELISA reader was used to reading the ELISA plate at $450 \mathrm{~nm}$.

\subsection{Preparation and Purification of Plasmid.}

The bacterial clones were inoculated into $5 \mathrm{ml}$ LB medium containing $5 \mu \mathrm{Amp}$ (100 $\mathrm{mg} / \mathrm{ml}$ ) for isolation of plasmid containing VHH gene. The mixture was incubated with vigorous shaking at $37^{\circ} \mathrm{C}$ for $14-16 \mathrm{~h}$. Then the bacteria were harvested by spinning at 11000 $\mathrm{xg}$ for $1 \mathrm{~min}$, and the pellet (contain the plasmid) was purified according to the protocol of Qiagen company (Qiagen Kit, Germany).

\subsection{Amplification of VHH (Nanobodies) using Polymerase Chain Reaction.}

Amplification of VHH (Nanobodies) was performed by the PCR technique using G111 (5' CCACAGACAGCCCTCATAG '3) and PM57 (5' TTATGCTTCCGGCTCGTATG '3) primers. The reaction was performed in a final volume of $25 \mu \mathrm{l}$ as following, $1 \mu 1$ of purified plasmid was mixed with $12.5 \mu \mathrm{l}$ of $2 \mathrm{x}$ master mix Promega and $1 \mu \mathrm{l}$ of each primer at a concentration of $10 \mathrm{pmol} / \mu \mathrm{l} "$. Parameters of PCR amplification were started by initial denaturation at $94^{\circ} \mathrm{C}$ for $5 \mathrm{~min}$ followed by 20 cycles of $94^{\circ} \mathrm{C}$ for $30 \mathrm{~s}, 55^{\circ} \mathrm{C}$ for $1 \mathrm{~min}, 72^{\circ} \mathrm{C}$ for $1 \mathrm{~min}$ and ended with Final extension at $72^{\circ} \mathrm{C}$ for $7 \mathrm{~min}$ in a thermocycler (Veriti 96 well, $\mathrm{AB}$, Singapore). The success of amplification was tested by loading the amplified samples on $1 \%$ agarose gel and running on the gel electrophoresis system and investigated on gel documentation system (UVP, USA).

\subsection{Expression and purification of nano-bodies.}

Nano-bodies were expressed in E. coli WK6 cells and then purified according to protocols described by Vasylieva et al. [23] using a Ni-NTA Spin Kit (Qiagen, Germany) according to the manufacturer's protocol. Nanobodies purification was confirmed by loading $20 \mu \mathrm{l}$ of each nano-body on $12 \%$ mini SDS-PAGE separating gel and $4 \%$ Stacking Gel stained with coomassie blue dye and the samples were run under the running condition of 200 volts for approximately $45 \mathrm{~min}$ [24]. The reactivity of nano-bodies was analyzed by Western blot using the standard transfer protocol from the Bio-Rad preprogrammed protocols or the user-defined protocol and binding with monoclonal anti-poly-histidine antibody (Sigma-Aldrich, Germany) for the detection.

\subsection{Nanobody-based sandwich-ELISA.}

ELISA reaction was performed to test the selected specific nano-bodies against $S$. arizonae. A microplate was coated with $0.25 \mu \mathrm{g} \mathrm{ml}^{-1}$ of rabbit polyclonal antibody ( $100 \mu \mathrm{l} /$ well) overnight at $4{ }^{\circ} \mathrm{C}$. The unbound sites in the microplate were blocked with $3 \%(\mathrm{w} / \mathrm{v})$ skimmed milk (300 $\mu \mathrm{l} /$ well) in PBS. After rinsing each well with PBST, serial concentrations of $S$. arizonae was added to the wells $(100 \mu \mathrm{l} /$ well $)$ and incubated for $1 \mathrm{~h}$. Then, $100 \mu \mathrm{l}$ of purified nano-body $\left(4 \mu \mathrm{g} \mathrm{ml}^{-1}\right)$ was added and incubated at $37{ }^{\circ} \mathrm{C}$ for $1 \mathrm{~h}$. After washing, the microplate was incubated with an anti-HA tag antibody conjugated with HRP for another $1 \mathrm{~h}$ and 
subsequently washed. Freshly prepared TMB substrate $(100 \mu \mathrm{l} /$ well $)$ was added to each well. Incubation was carried out at $37^{\circ} \mathrm{C}$ for $10 \mathrm{~min}$, and the reaction was stopped by $50 \mu 1$ of $2 \mathrm{M}$ $\mathrm{H}_{2} \mathrm{SO}_{4}$. Then the absorbance value of each well at $450 \mathrm{~nm}$ was detected using a microplate reader.

\section{Results and Discussion}

\subsection{Camel immunization.}

S. arizonae is the common environmental pathogenic bacteria in various vital fields, and it can cause serious illnesses for humans and animals [25]. Thus, the current research manuscript was conducted to produce nano-bodies for the fasting diagnostic of $S$. arizonae. To achieve this aim, the construction of VHH library was based on immunization of one male camel with formalin killed vaccine of $S$. arizonae. The detection of camel immune response against $S$. arizonae was determined by isolation of plasma antibody (Ab) that measured by ELISA, as described in Fig. (1). Immunized camel with $S$. arizonae produced a high ELISA $\mathrm{Ab}$ titer, so the sample diluted $10^{3}$. The $\mathrm{OD}_{450}$ value of the diluted sample was 1.353 , and the OD 450 value of PBS as a sample control was 1.252.

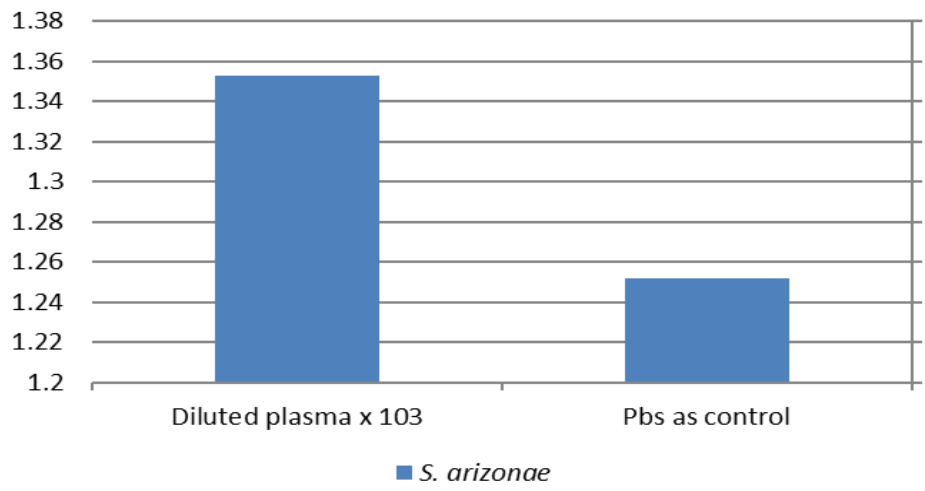

Figure 1. The response of immunized camel antibodies against $S$. arizonae in plasma measured by ELISA, where the plasma dilutions $10^{-3} \mathrm{OD}_{450}$ value was 1.353 , while PBS control was 1.252

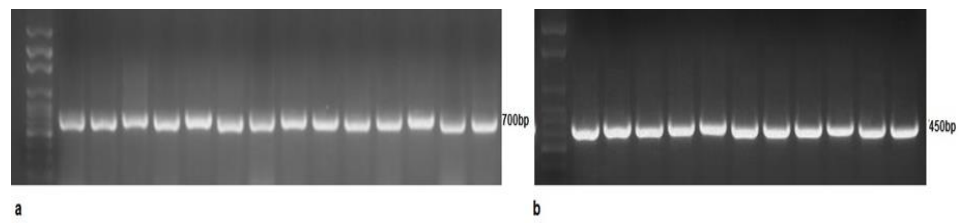

Figure 2. Amplification of VHH through two successive PCR CAL and nested VHH were performed; a, showed success of CAL PCR amplification using Cal001 and Cal002 primers on 1\% agarose gel electrophoresis, the isolated fragment was at $700 \mathrm{bp}$; b, showed amplification and success of nested PCR for VHH domains at $450 \mathrm{bp}$.

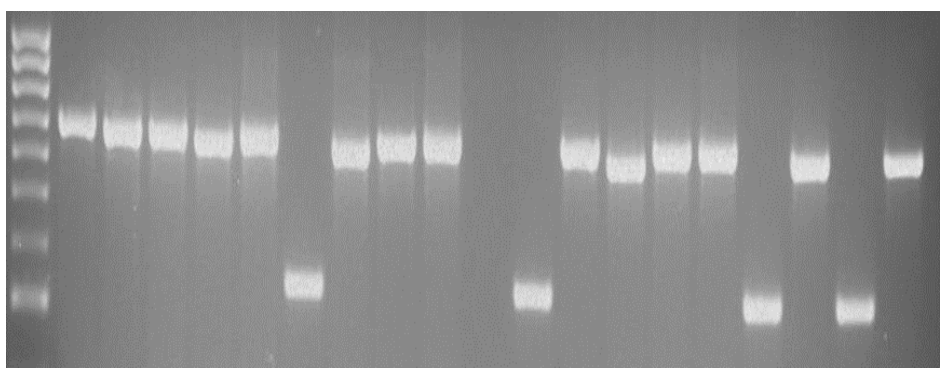

Figure 3. The camel VHH library construction where the success of a positive colony reached to $74 \%$ by investigation on $1 \%$ agarose gel electrophoresis. 


\subsection{Production of immunized VHH library (IVHHL).}

To produce the immunized VHH library, the total RNA was isolated from the collected vaccinated camel blood and reversely transcribed into cDNA in order to amplify VHH fragments through two successive PCR amplification. The first amplification was Cal PCR that produced fragment length at $700 \mathrm{bp}$, which contains all VH domains of IgG2 and IgG3 isotypes followed by the second amplification VHH PCR with amplified fragments at 450 bp (Fig. 2a and $2 b$ ). The nested PCR and pMECS vector were digested with PstI and NotI restriction enzymes and then ligated together. The ligated vector and VHH were prepared for cloning step by electro-transformation into Escherichia coli TG1 cells (the preferred and suitable E coli cells for producing the high yield of $\mathrm{VHH}$ by phage), the success of transformation was tested by colony PCR producing $85 \%$ success by testing on $1 \%$ agarose gel (Fig. 3 ).

\subsection{Phage display selection of nano-antibody to S. arizonae.}

To select specific phages displaying an immunized library (IVHHL) against $S$. arizonae, IVHHL was added to helper phage and bio-panning Pan 0 was prepared for isolating rescue phage. Besides, four rounds of bio-panning Pan 1, Pan 2, Pan 3, and Pan 4 were performed using $S$. arizonae as antigen such that used in camel vaccination. All the pans showed complete fusion between nano-bodies and antigen. Furthermore, the concentration of rescue phage was determined for four pans where Pan 3 and Pan 4 exhibited the highest specificity of nano-antibodies against the antigen, in corresponding to the control rather than Pan 1 and Pan 2. All Pans were diluted to the lowest one in order to isolate the rescue phage. The success of phage display analysis and the maturation of camel nano-antibodies were checked by colonies counting and phage ELISA.

Colonies counting was detected as an increase in colony quant from Pan 1 to Pan 3 then become stable in Pan 4 where, Pan 1 expressed $3 * 10^{4}, 2.3 * 10^{4}$ in Pan 2 corresponding to $1 * 10^{2}$ control and $1.1^{*} 10^{5}$ in Pan 3 and $7 * 10^{5}$ in pan 4 , the control was zero in pan 3 and 4 control (Table 1).

The Phage ELISA was proved the success of phage display and the maturation of nanobodies, wherever the specify of nano-bodies was increased from P1 to Pan 3, while Pan 4 possessed the same specifications as in Pan 3 (Fig. 4).

Table 1. Colony quant in LB agar media with AMP and Glu for each Pan to detect the specify of camel nanobodies against $S$. arizonae.

\begin{tabular}{|c|c|c|c|c|c|c|c|}
\hline & $\begin{array}{l}\text { Pan1 } \\
\text { Antigen }\end{array}$ & $\begin{array}{l}\text { Pan2 } \\
\text { antigen }\end{array}$ & Control & $\begin{array}{l}\text { Pan3 } \\
\text { antigen }\end{array}$ & Control & $\begin{array}{l}\text { Pan4 } \\
\text { antigen }\end{array}$ & Control \\
\hline $\begin{array}{l}\text { S. arizonae } \\
\text { phage }\end{array}$ & $3.0 * 10^{4}$ & $2.3^{*} 10^{4}$ & $1 * 10^{2}$ & $1.1 * 10^{5}$ & 0 & $7 * 10^{5}$ & 0 \\
\hline
\end{tabular}

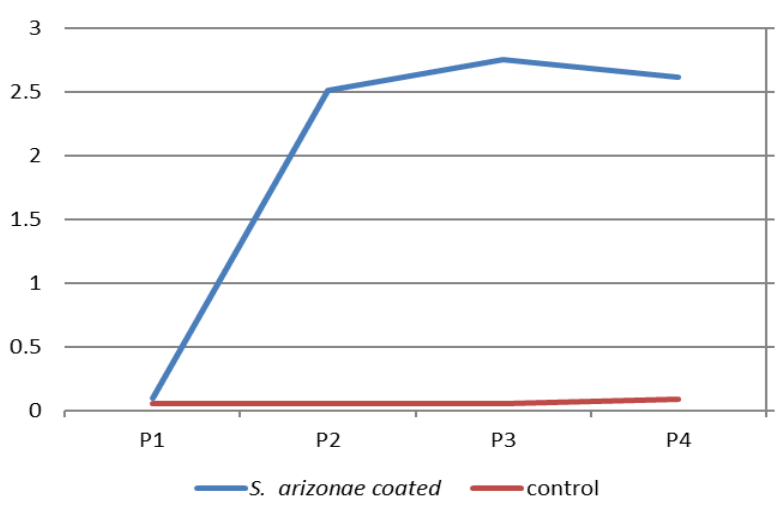

Figure 4. Screening for $S$. arizonae specific nano-bodies by Phage ELISA. 


\subsection{Screening for S. arizonae specific nano-antibody by ELISA.}

ELISA measures were performed for screening specificity of VHH fragments for $S$. arizonae using 48 different colonies of Pan 4 wherever Elisa OD/450nm value of nano-bodies for each clone was measured referring to the control, therefore, 5 out of 48 nano-bodies $(\mathrm{Nb}$ S. a-15: 0.954), (Nb-S. a-20: 0.977), (Nb-S.a-29 : 1.003), ( Nb-S.a-30 : 0.971), and (Nb-S.a-43 $: 1.06$ ) that possessed the highest OD/450nm were chosen (Fig. 5). Nano-bodies were purified cloned and isolated under non-denaturing conditions for preserving their functional protein configuration, and the reactivity of each $\mathrm{VHH}$ of the selected nano-bodies was analyzed by Western blot assay.

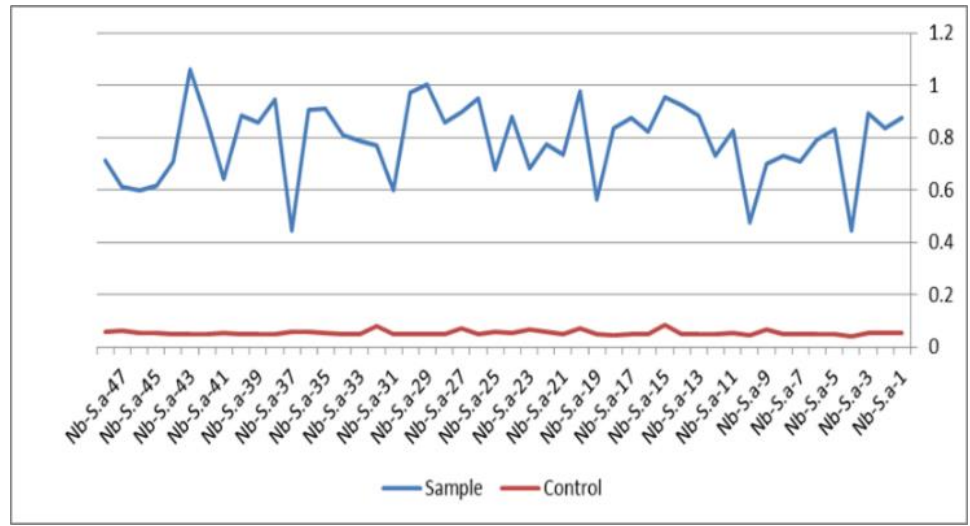

Figure 5. ELISA OD/450nm value of different 48 colonies marked with blue columns and its control with red columns, 5 Nano-antibodies (Nb-S.a-15 : 0.954), (Nb-S.a-20 : 0.977), , (Nb-S.a-29 : 1.003), ( Nb-S.a-30 : 0.971), and (Nb-S.a-43 : 1.06) according to highest ELISA OD value were selected against S. arizonae.

Nano-bodies protein was purified and separated under non-denaturing conditions by SDS-PAGE and visualized by Coomassie staining [26]. The reactivity of each VHH of the selected clones was analyzed by Western blot assay, where nano-bodies were probed with monoclonal anti-poly-histidine antibody and GAMAP and stained with NBT/BCIP substrate (Fig. 6).

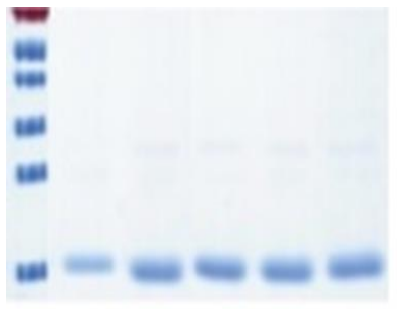

a

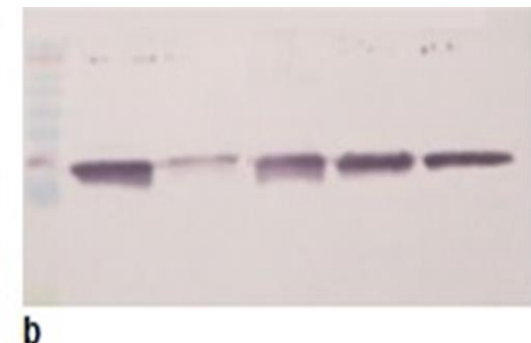

b

Figure 6. The selected nano-bodies were separated by SDS-PAGE and visualized by Coomassie staining (Fig. 6a). Western blot assay was performed for detecting the binding specificity of nano-bodies Fig. 6b) where VHH was probed with monoclonal anti-poly-histidine antibody and GAMAP and stained with NBT/BCIP substrate.

\subsection{ELISA Competition.}

The ability of nano-bodies binding to $S$. arizonae was evaluated by competitive binding assays of nano-bodies with Salmonella typhimurium. Fig. (7) illustrated the competitive assays of previously selected five clones of $S$. arizonae, Nb-S.a-15, Nb-S.a-20, Nb-S.a-29, Nb-S.a-30, and $\mathrm{Nb}-\mathrm{S} . \mathrm{a}-43$. Nano-bodies showed the highest immune response against $S$. arizonae regarding the Salmonella typhimurium. In the clone Nb-S.a-43, OD/450nm value of nanobodies showed the highest value (1.044) against $S$. arizonae in comparison with OD/450nm value 0.556 against $S$. typhimurium, in the clone $\mathrm{Nb}-\mathrm{S} . \mathrm{a}-29$, it has high OD/450nm value 
possessed the highest value 1.025 against $S$. arizonae compared against $S$. typhimurium $\mathrm{OD} / 450 \mathrm{~nm}$ value was 0.67 , in the clone $\mathrm{Nb}-\mathrm{S}$.a-20 possessed the highest OD/450nm value 1.023 against $S$. arizonae, whereas $0 D / 450 \mathrm{~nm}$ value demonstrated 1.009 against $S$. typhimurium, in the clone Nb-S.a-30 possessed the highest OD/450nm value 0.871 against $S$. arizonae, whereas OD/450nm value demonstrated 0.867 against $S$. typhimurium, while in the clone Nb-S.a-15 determined the higher value of OD/450nm 0.834 against $S$. typhimurium than, OD/450nm value was 0.795 against $S$. arizonae [27-29].

The proposed assay didn't show much superiority in terms of sensitivity compared with other reported immunoassays. The reason might due to the traditional colorimetric reaction using TMB as a substrate. In order to improve its sensitivity in the future, this method could be combined with other HRP-mediated assays, including chemiluminescent [30,31], fluorescence [32], and plasmonic ELISA [33,34]. Nanobodies, with advantages of high stability and easy genetic manipulation, make it possible to generate recombinant chimeric or tagged fragments that enable improvements in immunoassays [35-40].

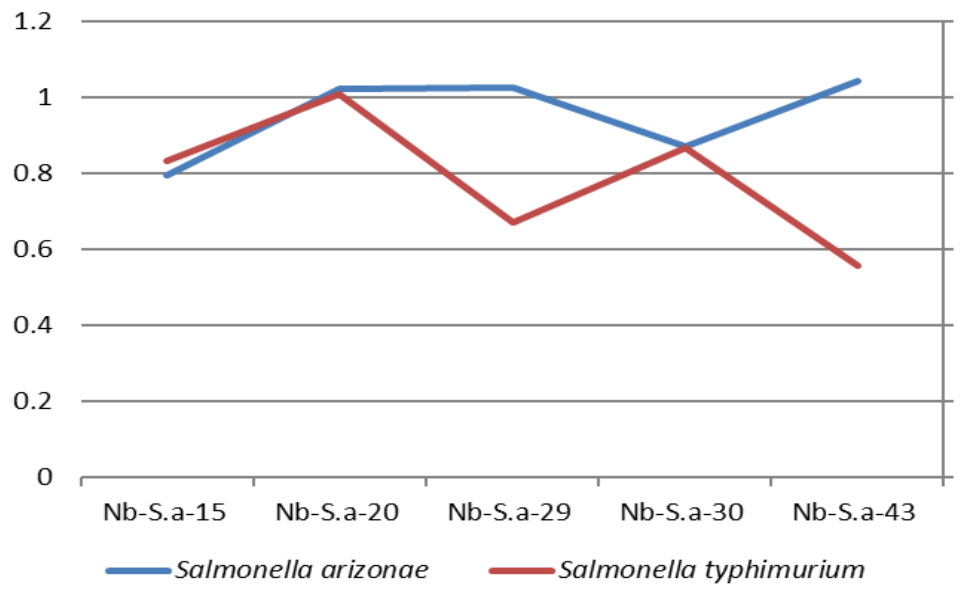

Figure 7. The competitive ELISA assays of 4 selected nano-bodies against S. arizonae, Nb-S.a-20, Nb-S.a-29, $\mathrm{Nb}-\mathrm{S} . \mathrm{a}-30$, and Nb-S.a-43, showed the highest immune response regarding the $S$. typhimurium. In contrast, the nano-body $\mathrm{Nb}-\mathrm{S}$.a-15 showed $\mathrm{OD} / 450 \mathrm{~nm}$ value agents $S$. arizonae lower than S. typhimurium.

\section{Conclusions}

In the current study, we developed a sandwich ELISA based on a nano-body towards S. arizonae as the first step for the detection of these pathogens. This is considered the first report of the development of nano-bodies for the treatment of $S$. arizonae. The isolated nanobodies showed binding not only to S. arizonae, but also to another Salmonella strains, indicating that these nano-bodies can be used for treatment but can't use in diagnostic. So, many trials should be done to improve its sensitivity in the future.

\section{Funding}

This research received no external funding.

\section{Acknowledgments}

The authors wish to thank the contribution between the Biochemistry Department, Faculty of Agriculture, Cairo University, Egypt and Agricultural Microbiology Department, National Research Centre, Giza, Egypt, for their supporting of this work. 


\section{Conflicts of Interest}

\section{The authors declare no conflict of interest.}

\section{References}

1. Darwesh, O.M.; Barakat, K.M.; Mattar, M.Z.; Sabae, S.Z.; Hassan, S.H. Production of antimicrobial blue green pigment Pyocyanin by marine Pseudomonas aeruginosa. Biointerface Research in Applied Chemistry 2019, 9, 4334-4339, https://doi.org/10.33263/BRIAC95.334339.

2. Riley, K.B.; Antoniskis, D.; Maris, R.; Leedom, J.M. Rattlesnake capsule-associated Salmonella arizonae infections. Archive of International journal of Medicine 1988, 148, 1207-1210.

3. Caldwell, M.E.; Ryerson, D.L. Salmonellosis in Certain Reptiles. Journal of Infection Disease 1939, 65, 242-245.

4. Tindall, B.J.; Grimont, P.A.; Garrity, G.M.; Euzeby, J.P. Nomenclature and taxonomy of the genus Salmonella. International Journal of Systematic Evolution and Microbiology 2005, 55, 521-524, https://doi.org/10.1099/ijs.0.63580-0.

5. Di Bella, S.; Capone, A.; Bordi, E.; Johnson, E.; Musso, M.; Topino, S.; Noto, P.; Petrosillo, N. Salmonella enterica ssp. arizonae infection in a 43-year-old Italian man with hypoglobulinemia: a case report and review of the literature. Journal of Medical Case Report 2011, 5, 323-340, https://doi.org/10.1186/1752-1947-5323.

6. Andrews, M.D. Arizona group gastroenteritis. Journal of Okla State Medicine Association 1970, 63, 421425 .

7. Centers for Disease Control (CDC). Arizona hinshawii septicemia associated with rattlesnake powderCalifornia. MMWR Morbial Morta Wkly Report 1983, 32, 464-465.

8. Smilack, J.D.; Goldberg, M.A. Bone and joint infection with Arizona hinshawii: report of a case and a review of the literature. American Journal of Medical Science 1975, 270, 503-507, https://doi.org/10.1097/00000441-197511000-00012.

9. Kolker, S.; Itsekzon, T.; Yinnon, A.M.; Lachish, T. Osteomyelitis due to Salmonella enterica subsp. arizonae: the price of exotic pets. Clinical Microbiology and Infection 2012, 18, 167-170, https://doi.org/10.1111/j.1469-0691.2011.03533.x.

10. Hoag, J.B.; Sessler, C.N. A comprehensive review of disseminated Salmonella arizona infection with an illustrative case presentation. South Medical Journal 2005, 98, 1123-1129, https://doi.org/10.1097/01.smj.0000177346.07719.00.

11. Eida, M.F.; Darwesh, O.M.; Matter, I.A. Cultivation of oleaginous microalgae Scenedesmus obliquus on secondary treated municipal wastewater as growth medium for biodiesel production. Journal of Ecological Engineering 2018, 19, 38-51.

12. Schneider, L.; Ehlinger, M.; Stanchina, C.; Giacomelli, M.C.; Gicquel, P.; Karger, C.; Clavert, J.M. Salmonella enterica subsp. arizonae bone and joints sepsis. A case report and literature review. Orthopology Traumatology and Surgical Research 2009, 95, 237-242, https://doi.org/10.1016/j.otsr.2008.09.010.

13. Hamers-Casterman, C.; Atarhouch, T.; Muyldermans, S.; Robinson, G.; Hamers, C.; Songa, E.B.; Bendahman, N.; Hamers, R. Naturally-occurring antibodies devoid of light-chains. Nature 1993, 363, 446448, https://doi.org/10.1038/363446a0.

14. Maass, D.R.; Sepulveda, J.; Pernthaner, A.; Shoemaker, C.B.; Alpaca (Lama pacos) as a convenient source of recombinant camelid heavy chain antibodies (VHHs). Journal of Immunological Methods 2007, 324, 1325, https://dx.doi.org/10.1016\%2Fj.jim.2007.04.008.

15. Bratkovic, T. Progress in phage display: evolution of the technique and its application. Cells and Molecular Life Science 2010, 67, 749-767, https://doi.org/10.1007/s00018-009-0192-2.

16. Gene, R.W.; Kumaran, J.; Aroche, C.; Van Faassen, H.; Hall, J.C.; MacKenzie, C.R.; Arbabi-Ghahroudi, M. High affinity anti-internalin B VHH antibody fragments isolated from naturally and artificially immunized repertoires. Journal of Immunological Methods 2015, 416, 29-39, https://doi.org/10.1016/j.jim.2014.10.009.

17. Darwesh, O.M.; Matter, I.A.; Eida, M.F. Development of peroxidase enzyme immobilized magnetic nanoparticles for bioremediation of textile wastewater dye. Journal of Environmental Chemical Engineering 2019, 7, https://doi.org/10.1016/j.jece.2018.11.049.

18. Galleni, M.; Muyldermans, S.; Kinne, J.; Wyns, L.; Conrath, K. E.; Frere, J.M.; Lauwereys, M. Lactamase inhibitors derived from single-domain antibody fragments elicited in the camelidae. Antimicrobial Agents and Chemotherapy 2002, 45, 2807-2812, https://doi.org/10.1128/aac.45.10.2807-2812.2001.

19. Ren, X.; Yan, J.; Wu, D.; Wei, Q.; Wan, Y. Nanobody-based apolipoprotein e immunosensor for point-ofcare testing. ACS Sensors 2017, 2, 1267-1271, https://doi.org/10.1021/acssensors.7b00495.

20. He, Y.; Ren, Y.; Guo, B.; Yang, Y.; Ji, Y.; Zhang, D.; Wang, J.; Wang, Y.; Wang, H. Development of a specific nano-body and its application in rapid and selective determination of Salmonella enteritidis in milk. Food Chemistry 2020, 310, https://doi.org/10.1016/j.foodchem.2019.125942.

21. Darwesh; O.M.; Eida, M.F.; Matter, I.A. Isolation, screening and optimization of L-asparaginase producing bacterial strains inhabiting agricultural soils. Bioscience Research 2018, 15, 2802-2812. 
22. Xue, X.; Fan, X.; Qu, Q.; Wu, G. Bioscreening and expression of a camel anti-CTGF VHH nano-body and its renaturation by a novel dialysis-dilution method. AMB Express 2016, 6, 1-11, https://doi.org/10.1186/s13568-016-0249-1.

23. Vasylieva, N.; Zhang, J.; Li, Z.; Hammock, B.D.; Huo, J.; Qi, M.; Barnych, B. Development of a highly sensitive direct competitive fluorescence enzyme immunoassay based on a nano-body-alkaline phosphatase fusion protein for detection of 3-phenoxybenzoic acid in urine. Journal of Agricultural and Food Chemistry 2018, 66, 11284-11290, https://doi.org/10.1021/acs.jafc.8b04521.

24. Barakat, K.M.; Mattar, M.Z.; Sabae, S.Z.; Darwesh, O.M.; Hassan, S.H. Production and Characterization of Bioactive Pyocyanin Pigment by Marine Pseudomonas aeruginosa OSh1. Research Journal of Pharmaceutical, Biological and Chemical Sciences 2015, 6, 933-943.

25. Bell, R.L.; Jarvis, K.G.; Ottesen, A.R.; Mcfarland, M.A.; Brown, E.W. Recent and emerging innovations in Salmonella detection: A food and environmental perspective. Microbial Biotechnology 2016, 9, 279-292, https://doi.org/10.1111/1751-7915.12359.

26. Darwesh, O.M.; Ali, S.S.; Matter, I.A.; Elsamahy, T.; Mahmoud, Y.A. Enzymes immobilization onto magnetic nanoparticles to improve industrial and environmental applications. Methods in Enzymology, ISSN: 00766879 2020, 630, 481-502, https://doi.org/10.1016/bs.mie.2019.11.006.

27. Kumar, S.; Balakrishna, K.; Batra, H.V. Enrichment-ELISA for detection of Salmonella typhi from food and water samples. Biomedical and Environmental Sciences: BES 2008, 21, 137-143, https://doi.org/10.1016/S0895-3988(08)60019-7.

28. Ali, S.I.; Mohamed, A.A.; Sameeh, M.Y.; Darwesh, O.M.; Abd El-Razik, T.M. Gamma-Irradiation Affects Volatile Oil Constituents, Fatty Acid Composition and Antimicrobial Activity of Fennel (Foeniculum vulgare) Seeds Extract. Research Journal of Pharmaceutical, Biological and Chemical Sciences 2016, 7 , 524-532.

29. Wang, W.; Liu, L.; Song, S.; Tang, L.; Kuang, H.; Xu, C. A highly sensitive ELISA and immunochromatographic strip for the detection of Salmonella typhimurium in milk samples. Sensors (Switzerland) 2015, 15, 5281-5292, https://doi.org/10.3390/s150305281.

30. Wu, X.; Wang, W.; Liu, L.; Kuang, H.; Xu, C. Monoclonal antibody-based cross reactive sandwich ELISA for the detection of Salmonella spp. in milk samples. Analytical Methods 2015, 7, 9047-9053, https://doi.org/10.1039/C5AY01923K.

31. Wang, C.; Xing, K.; Zhang, G.; Yuan, M.; Xu, S.; Liu, D.; Lai, W.H. Novel ELISA based on fluorescent quenching of DNA-stabilized silver nanoclusters for detecting E. coli O157:H7. Food Chemistry 2019, 281, 91-96, https://doi.org/10.1016/J.FOODCHEM.2018.12.079.

32. Zhu, F.; Peng, J.; Huang, Z.; Hu, L.; Zhang, G.; Liu, D.; Lai, W. Specific colorimetric ELISA method based on DNA hybridization reaction and non-crosslinking gold nanoparticles aggregation for the detection of amantadine. Food Chemistry 2018, 257, 382-387, https://doi.org/10.1016/J.FOODCHEM.2018.03.033.

33. Fang, Q.; Wang, L.; Hua, X.; Wang, Y.; Wang, S.; Cheng, Q.; Liu, F. An enzyme-linked chemiluminescent immunoassay developed for detection of Butocarboxim from agricultural products based on monoclonal antibody. Food Chemistry 2015, 166, 372-379, https://doi.org/10.1016/J.FOODCHEM.2014.06.060.

34. Pírez-Schirmer, M.; Brena, B.M.; González-Sapienza, G. Oriented functionalization of magnetic beads with in Vivo biotinylated nano-bodies for rapid MALDI-TOF MS ultrasensitive quantitation of microcystins in biological samples. Analytical Chemistry 2019, 91, 9925-9931, https://doi.org/10.1021/acs.analchem.9b01596.

35. Ahmadian, S.; Orlov, Y.L.; Maurady, A.; Eslami, G.; Hosseini, S.S. Rna polymrase ii gene expression in clinical leishmania major isolates with no-response-to-drug pattern. Biointerface Research in Applied Chemistry 2019, 9, 4126-4130.

36. Kheiralla, Z.H.; Hewedy, M.A.; Mohammed, H.R.; Darwesh, O.M. Isolation of Pigment Producing Actinomycetes from Rhizosphere Soil and Application It in Textiles Dyeing. Research Journal of Pharmaceutical, Biological and Chemical Sciences 2016, 7, 2128-2136.

37. Topel, S.D.; Topel, Ö.; Cin, G.T. Fabrication and characterization of tio<inf $>2</$ inf $>$ nanoparticles conjugated luminescence upconversion nanoparticles. Biointerface Research in Applied Chemistry 2018, 8, 3197-3202.

38. Jamous, S.; Burlibaşa L. New insights in molecular analysis of gene regulation - an epigenetic overview. Letters in Applied NanoBioScience 2018, 7, 511 - 522.

39. Marrez, D.A.; Abdelhamid, A.E.; Darwesh, O.M. Eco-friendly cellulose acetate green synthesized silver nano-composite as antibacterial packaging system for food safety. Food Packaging and Shelf Life 2019, 20, 1-8, https://doi.org/10.1016/j.fpsl.2019.100302.

40. Yazdani, E.; Talebi, M.; Zarshenas, M.M.; Moein, M. Evaluation of possible antioxidant activities of barberry solid formulation, a selected formulation from traditional persian medicine (tpm) via various procedures. Biointerface Research in Applied Chemistry 2019, 9, 4517-1521. 